\title{
PÍSEČNÍK U JAVORNÍKU - DRUMLIN SE ZACHOVALOU SUKCESÍ SUBGLACIÁLNÍCH A SUPRAGLACIÁLNÍCH SEDIMENTŮ
}

\author{
Písečník Hill near Javorník - drumlin with preserved subglacial and supraglacial succession \\ of sediments
}

\author{
Martin Hanáček', Daniel Nývlt't ${ }^{2,3}$, Slavomír Nehyba' \\ 1 Ústav geologických věd, PřF MU, Kotlářská 267/2, 61137 Brno; e-mail: HanacekM@seznam.cz \\ ${ }^{2}$ Česká geologická služba, Leitnerova 22, 65869 Brno \\ ${ }^{3}$ Geografický ústav, Prírodovědecká fakulta, Masarykova univerzita, Kotlářská 267/2, 61137 Brno
}

(04-44 Javorník)

Key words: drumlin, subglacial sediments, lodgement till, boulder lag, supraglacial sediments, ice-cored moraine, dead-ice moraine, clast petrology and provenance, Javorník, Sudetes

\begin{abstract}
Písečník Hill (288 m a. s. l.) is an isolated elevation located near the Javorník town close to the NE foothill of the main ridge of the Rychleby Mts. (Eastern Sudetes). It has a shape of a ridge elongated in the SE-NW direction, made of compacted Miocene sands covered by Pleistocene tills and glaciofluvial sediments. These glacial sediments have been deposited during the Elsterian glaciation (MIS 12) according to the Northern European stratigraphical scale. The presented study is targeted on glacial deposits and the interpretation of the evolution of the Písečník Hill linked to continental glaciation. Facies description has been supplemented by petrographical analyses of the gravel fraction $16-64 \mathrm{~mm}$. The glacial sequence is composed of five members. The first one is a lodgement till (Jk1) with a basal boulder lag, which followed the erosional phase producing elongated scours. Glacitectonic features, such as plucking of underlying Miocene sands and formation of rip-up clasts could be seen in the lodgement till unit. Boulder lag with boulders up to $2 \mathrm{~m}$ long originated by blocking of large clasts in compact, plastic, unlithified basement. The second member (Jk2) is a massive to weakly stratified gravely sand, which filled a shallow depression in the lodgement till. These sediments originated by reworking of underlying till material. Members Jk1-Jk2 have been deposited in subglacial environment. Both members are equivalent from the viewpoint of petrological composition - they both contain predominantly local Gierattow gneiss. The third member (Jk3) is a coarse grained to bouldery gravel. The fourth member (Jk4) is made of a fine layer of laminated sand. The last member (Jk5) is a sandy gravel with gently sloping flat clasts. Members Jk3-Jk5 are interpreted as supraglacial sediments deposited with the ice-cored moraine environment. They are rather polymictic from petrological point of view, as they contain material of diverse provenance originating from different parts of the glacier. The clasts are also more variable in roundness with higher content of rounded to well-rounded clasts ("englacial egg gravel facies"). The Písečník Hill represents a drumlin with a core composed of plastic Miocene sand. Features described in the glacial sequence show on the active glacial movement (in subglacial environment), as well as the subsequent decay starting from the ice-cored moraine to the final disappearance of the dead-ice moraine. The drumlin orientation documents the ice sheet advance from the NE.
\end{abstract}

\section{Úvod a metodika}

Písečník (288 m n. m.) je izolovaná elevace ležící $600 \mathrm{~m}$ s. od Javorníku při sv. úpatí hlavního hřebene Rychlebských hor (obr. 1). Má tvar hřbetu dlouhého $\sim 0,5 \mathrm{~km}$ a protáhlého ve směru SV-JZ. Je tvořen relativně kompaktními miocenními písky (Pouba 1996), překrytými pleistocenními tilly a glacifluviálními písky a štěrky. Uvedené sedimenty jsou odkryty v malé pískovně na vrcholu hřbetu. Doposud byly ledovcové uloženiny na Písečníku studovány hlavně petrograficky (Pecina et al. 2005, Sikorová et al. 2006) a podle svého strukturního a texturního charakteru interpretovány jako supraglaciální melt-out tilly (Růžičková et al. 2003). Paleogeograficky leží studované ledovcové uloženiny v okrajové zóně pleistocenního kontinentálního zalednění a stratigraficky jsou kladeny do mladšího elsterského zalednění (Pecina et al. 2005). Tento příspěvek se zaměřuje na rozšírení interpretace depozičního prostředí ledovcových uloženin na Písečníku a rekonstrukci vývoje celé elevace během zalednění.

Pískovna je dnes téměř zavezená skládkou a studium je možné pouze v zachovalé západní stěně, ke které se vztahují i výsledky předkládaného výzkumu. Pouze část informací pochází z již nepř́stupné východní stěny. Sedimenty

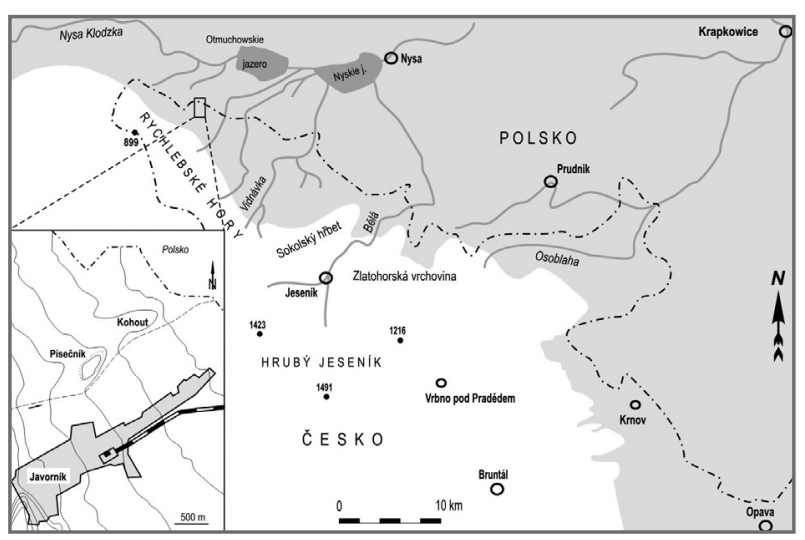

Obr. 1: Rozsah kontinentálního zalednění v předpolí Rychlebských hor, Zlatohorské vrchoviny a Jeseníků během druhého elsterského glaciálu. Šedě: kontinentální ledovec, bíle: nezaledněná oblast. Výřez: interval vrstevnic $-10 \mathrm{~m}$. Tečkovaná linie: tvar drumlinu.

Fig. 1: Northern European ice sheet extent in grey in the forefield of the Rychleby Mts., Zlaté Hory Highlands and Jeseník Mts. during the Elsterian glaciation (MIS 12); nn-glaciated are in white. Contour intervals of $10 \mathrm{~m}$ in the inset. Dotted line: drumlin shape. 
byly popisovány makroskopicky a v zakresleném profilu (obr. $2 \mathrm{~g}$ ) jsou rozlišeny zrnitostně podle největších klastů. Vzorky pro valounové analýzy byly odebírány z profilu pomocí lopatky a normalizovaného síta. Zkoumána byla frakce $16-64 \mathrm{~mm}$ v b-ose pro své reprezentativní zastoupení v sedimentech a dobrou petrografickou určitelnost klastů v tomto velikostním rozmezí. Orientačně byla analyzována i balvanitá frakce (61 klastů nad 256 mm v b-ose), ale v jejím př́ípadě se analýza vztahuje na celý vrstevní sled a nikoliv na některý z vymezených členů. Původ klastů byl určován podle geologických map Javornického výběžku a jejich vysvětlivek (Svoboda et al. 1961, Pouba et al. 1962, Sawicki 1995) a podle Gáby a Peka (1999) a Hesemanna (1975). Zaoblení bylo stanoveno podle Powerse (1953).

\section{Litofaciální vývoj sedimentů}

V západní stěně pískovny je odkryt nejúplnější sled všech sedimentů (obr. 2a). Miocenní písky jsou bělošedé až nahnědlé, jemnozrnné až hrubozrnné, špatně vytříděné a relativně kompaktní. Obsahují prríměs štěrčíku a drobného štěrku s klasty světlých rul. Ledovcové sedimenty nasedají na podloží s velmi výraznou výmolovou erozní bází. Litologicky jsou tvořeny pěti členy, označenými kódy Jk1-Jk5.

Člen Jk1 představuje masivní štěrkovitopísčitý diamikton $\mathrm{v}$ bezprostředním nadloží miocenních písků. Vyznačuje se značně proměnlivou mocností $(\sim 10-80 \mathrm{~cm})$ a v profilu vytváří dvě mocnější tělesa: Jk1a - diamikton vyplňující hlubokou erozní depresi a Jk1b - diamikton vyplňující sousední mělkou depresi.

Diamikton Jk1a začíná polohou velkých klastů, běžně dlouhých $\sim 15-25 \mathrm{~cm}$ a často subvertikálně orientovaných (obr. 2b). Nad bazální nejhrubší polohou se diamikton zjemňuje a hojně obsahuje klasty s délkou do $5 \mathrm{~cm}$. Převládá podpůrná struktura hrubozrnně písčité základní hmoty. Vyskytují se útržky podložních miocenních písků velké až $30 \mathrm{~cm}$ (šipka na obr. 2b). Místy se objevuje podpůrná struktura štěrkových klastů, která je charakteristická pro bazální nejhrubší polohu. Diamikton Jkla je mocný $\sim 80 \mathrm{~cm}$.

Diamikton Jk1b neobsahuje bazální nejhrubší polohu, největší klasty jsou dlouhé $\sim 15 \mathrm{~cm}$. Mocnost dosahuje $\max .50 \mathrm{~cm}$. V sedimentu se objevuje několik typů zrnitostních struktur (obr. 2c):

I (podpůrná struktura hrubozrnně písčité základní hmoty, $10 \%$ klastů do $3 \mathrm{~cm}$, ojediněle klasty dlouhé $\sim 10 \mathrm{~cm}$ ).

II (podpůrná struktura středno-hrubozrnně písčité základní hmoty, ojedinělé klasty do $5 \mathrm{~cm}$ ).

III (podpůrná struktura klastů dlouhých $\sim 3-10 \mathrm{~cm}$ ).

IV (podpůrná struktura jemně písčité základní hmoty, velmi podobné miocenním pískům, hojnost klastů dlouhých $\sim 3-10 \mathrm{~cm})$.

$V$ (podpůrná struktura jemně písčité základní hmoty s ojedinělými klasty do $5 \mathrm{~cm}$ ).

$V I$ (podpůrná struktura hrubozrnně písčité základní hmoty, prríměs štěrčíku, hojnost klastů nad $5 \mathrm{~cm}$ ).

VII (podpůrná struktura hrubozrnně písčité základní hmoty, příměs štěrčíku, výjimečně klasty dlouhé až $15 \mathrm{~cm}$ ).

Ojediněle se objevují znaky vyvlékání miocenních písků do diamiktonů (obr. 2d). Nepřítomnost velkých klastů na bázi diamiktonu Jk1b je spíše výjimkou, protože jinak byla prokázána i ve východní stěně pískovny (obr. 2e). Přímo na miocenním podloží mnohdy spočívají balvany o velikosti $\sim 25-120 \mathrm{~cm}$. Vůbec největší balvan tohoto horizontu má rozměry $200 \times 140 \times 115 \mathrm{~cm}$ a ležel také bezprostředně na miocenních píscích mezi členy Jk1a a Jk1b v západní stěně (viz obr. 80 v práci Růžičkové et al. 2003).

Člen Jk2 je špatně vytříděný sediment tvořený směsí hlavně hrubozrnného písku, štěrčíku a štěrku s velikostí klastů mezi 0,5 a $1,5 \mathrm{~cm}$. Větší klasty $(5 \mathrm{~cm})$ jsou zastoupeny $\mathrm{z} \sim 2-5 \%$. Hojně se objevují útržky podložních miocenních písků. Spodní část tohoto členu (Jk2a) má masivní texturu nebo místy slabě patrné šikmé zvrstvení. Ve svrchní části (Jk2b), spočívající nad nevýrazným štěrkovým horizontem, je zvrstvení stále zřetelnější a v nejvyšší části tohoto členu se již jedná o jasně šikmo zvrstvené středno-hrubozrnné písky s prríměsí štěrčíku (obr. 2f).

Člen Jk3 tvoří poloha hrubozrnného až balvanitého štěrku s hojnými klasty o délce až $30 \mathrm{~cm}$ (obr. 2f). Probíhá jen levou polovinou profilu. Podpůrnou strukturu tvoří hrubě písčitá základní hmota a štěrčík. Ploché klasty jeví horizontální uložení, izometrické klasty jsou uspořádány chaoticky. Mocnost štěrkové polohy činí $\sim 30 \mathrm{~cm}$.

Člen Jk4 je zvlněně laminovaný set středno- až hrubozrnného písku a štěrčíku, s příměsí větších štěrkových klastů. Hrubší polohy zaujímají spodní polovinu setu, svrchní polovina je písčitější. Laminace zřetelně kopíruje elevační tvar velkých klastů podložního členu (obr. 2f).

Člen Jk5 nasedá na podloží se slabě zvlněnou erozní bází. Jedná se o písčitý štěrk s hojností klastů velkých 0,5$1 \mathrm{~cm}$ a s $\sim 5-10 \%$ klastů nad $5 \mathrm{~cm}$ délky (obr. 2f). Největší klast je dlouhý $25 \mathrm{~cm}$. Hrubé klasty jsou více koncentrovány při bázi členu. Podpůrnou strukturu tvoří hrubozrnně písčitá základní hmota a štěrčík. Textura je masivní, pouze ploché klasty jsou mírně ukloněny. Zachovaná mocnost členu činí $\sim 40 \mathrm{~cm}$, celková mocnost není známa.

V pravé části západní stěny nejsou členy Jk3 a Jk4 přítomny. Sediment zde odpovídá členu Jk5, s největším klastem dlouhým min. $140 \mathrm{~cm}$ (pravý okraj obr. 2a). Vyznění štěrkové i nadložní písčité polohy je bohužel zastřeno destrukcí profilu ve střední části stěny.

\section{Petrografie a provenience štěrkových klastů a balvanů}

Ve štěrkové frakci je hlavní horninou bělošedá až načervenalá dvojslídná rula tvořící 28-78 \% valounů (tab. 1) a zastoupená několika texturními typy. Nejhojnějším je typ $\mathrm{s}$ výraznou foliací tvořenou stříáním křemen-živcových a slídových pásků ( 17-46\%), dále se vyskytují typy s nezřetelnou foliací, okatou nebo vzácně stébelnatou texturou, jemnozrnné velmi slabě usměrněné typy a hrubozrnné typy. Tyto horniny odpovídají gierałtowské rule (Svoboda et al. 1961). Dále se pravidelně vyskytují klasty amfibolitů, grafitického kvarcitu, dalších typů rul, šedých muskovitických kvarcitů, živcových kvarcitů a dvojslídných nebo muskovitických, někdy granátických svorů. Ojediněle se objevují klasty bělošedého granulitu. Klasty šedých granitoidů, které by mohly pocházet $\mathrm{z}$ variských granitoidních masivů v okolním krystaliniku, jsou velmi vzácné. Skladba klastů metamorfitů odpovídá litologii hlavního hřebene 

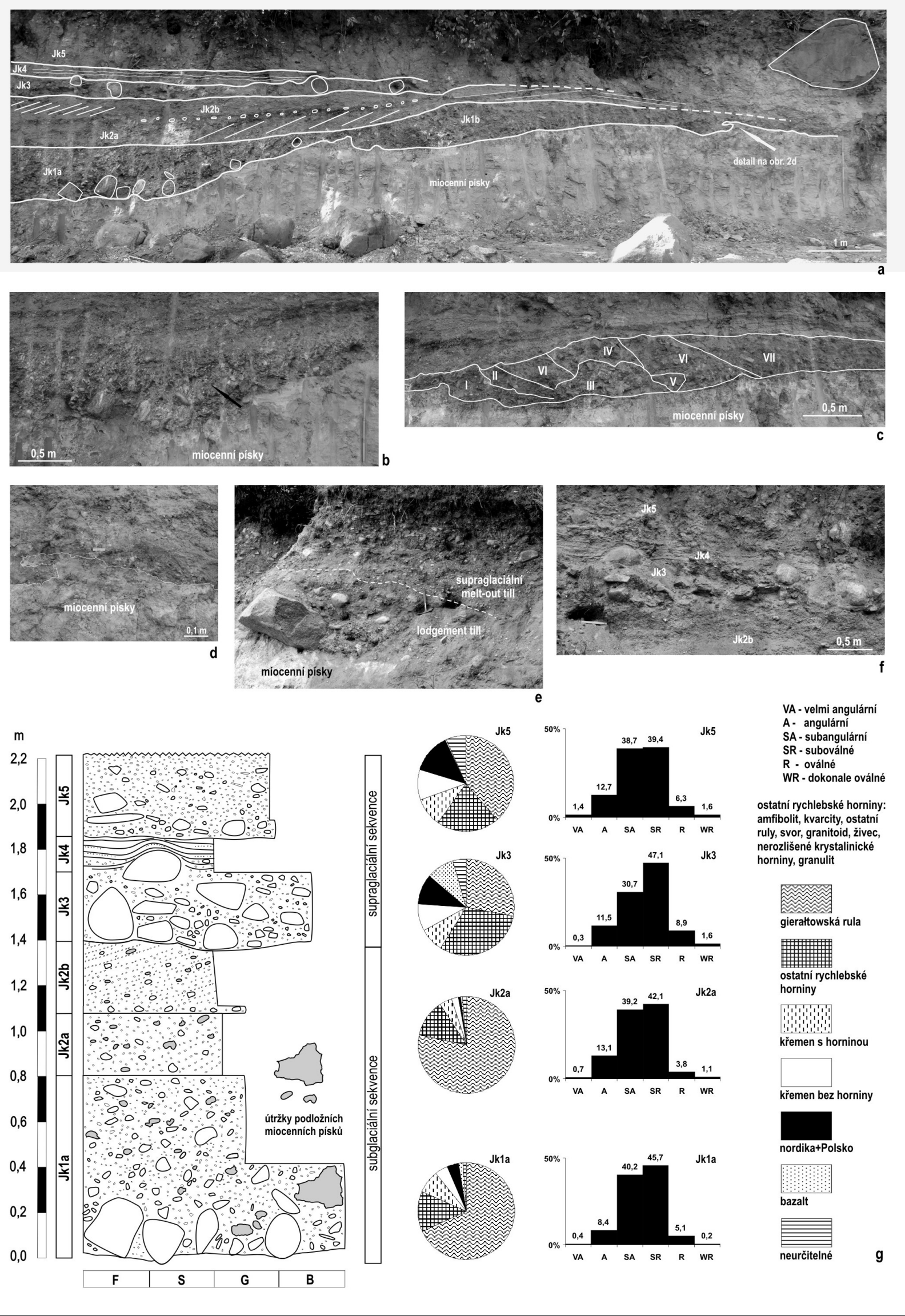

Obr. 2: Sedimentární architektura západní stěny pískovny na Písečníku, profil studovanými sedimenty, grafy petrografického složení a zaoblení štěrkových klastů.

Fig. 2: Sedimentary architecture of the western wall of the sandpit on the Písečník Hill including the logged section and graphs of petrographical composition and roundness of gravel clasts. 
Tab. 1: Petrografické a provenienční složení štěrkových klastů. Tab. 1: Petrographical and provenance composition of gravelly clasts.

\begin{tabular}{|c|c|c|c|c|c|}
\hline & petrografické typy klastů & Jk1a \% & Jk2a \% & $\mathrm{Jk} 3 \%$ & $\mathrm{Jk} 5 \%$ \\
\hline \multirow{11}{*}{ 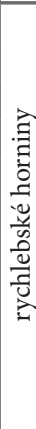 } & bělošedá a růžová rula & 68,08 & 78,26 & 28,19 & 38,50 \\
\hline & amfibolit & 2,38 & 0,54 & 7,93 & 2,82 \\
\hline & grafitický kvarcit & 2,04 & 4,17 & 5,29 & 5,32 \\
\hline & ostatní ruly & 1,87 & 2,72 & 5,73 & 2,35 \\
\hline & ostatní kvarcity & 1,02 & - & 1,76 & 1,88 \\
\hline & svor & 0,85 & 0,36 & 3,52 & 2,35 \\
\hline & granulit & 0,34 & - & - & - \\
\hline & bělošedý granitoid & 0,17 & - & 0,22 & 0,47 \\
\hline & izolovaný šedý K-živec & - & - & - & 0,31 \\
\hline & nerozliš. krystalinické horniny & 4,92 & 4,89 & 6,17 & 5,63 \\
\hline & rychlebské horniny celkem & 81,67 & 90,94 & 58,81 & 59,63 \\
\hline \multirow{3}{*}{$\begin{array}{l}\frac{1}{5} \\
0 \\
0\end{array}$} & sudetský porfyr & - & - & - & 0,63 \\
\hline & silicit & - & - & 0,22 & 0,47 \\
\hline & polské horniny celkem & - & - & 0,22 & 1,10 \\
\hline \multirow{10}{*}{ 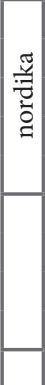 } & krystalinické horniny & 2,38 & 0,72 & 7,49 & 8,14 \\
\hline & pískovce a slepence & 1,19 & 0,18 & 2,42 & 3,91 \\
\hline & pazourek & 0,17 & - & - & - \\
\hline & pelosideritové a Fe konkrece & 0,17 & - & - & 0,16 \\
\hline & nordické horniny celkem & 3,91 & 0,90 & 9,91 & 12,21 \\
\hline & křemen se zbytky horniny & 7,64 & 4,17 & 8,15 & 9,70 \\
\hline & křemen bez zbytku horniny & 4,41 & 2,17 & 9,03 & 10,49 \\
\hline & bazalt & 1,19 & 0,36 & 9,47 & 0,16 \\
\hline & neurčitelné & 1,19 & 1,45 & 4,41 & 6,73 \\
\hline & celkový počet klastů & 589 & 552 & 454 & 639 \\
\hline
\end{tabular}

Rychlebských hor (Svoboda et al. 1961, Pouba et al. 1962). Kontinentální ledovec tento materiál nejpravděpodobněji redeponoval $\mathrm{z}$ aluviálních až fluviálních sedimentů, které se během glaciálů, ještě před zásahem ledovce, v předpolí Rychlebských hor ukládaly. Nelze vyloučit původ některých rul, svorů a amfibolitů v přilehlé části Polska, kde

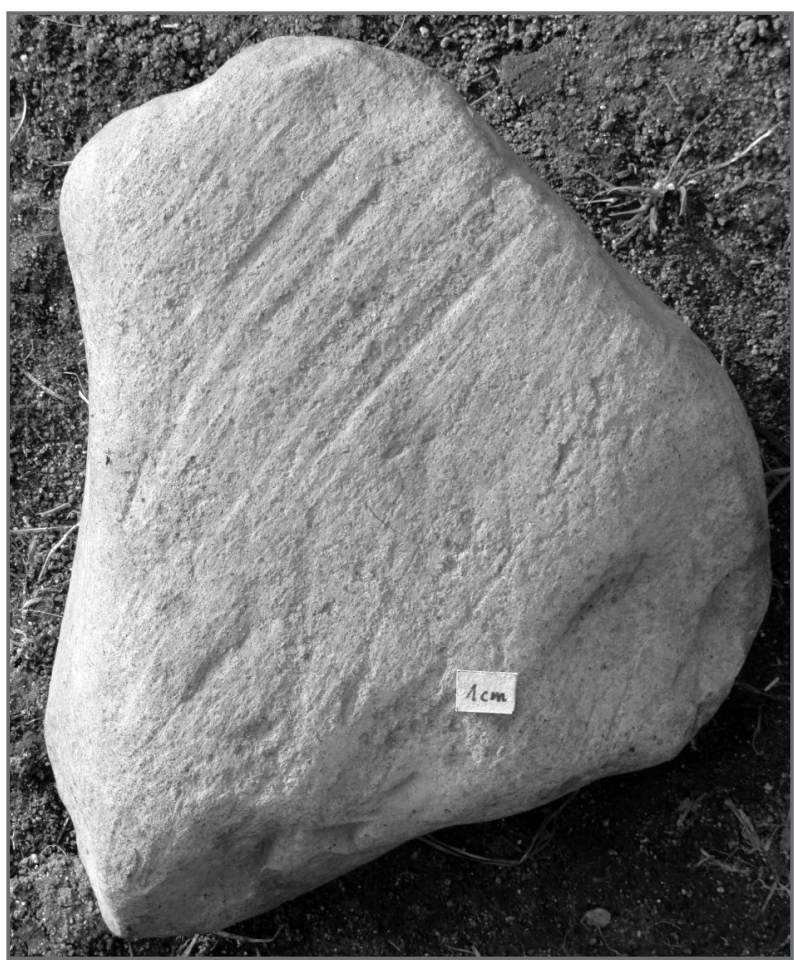

Obr. 3: Rýhovaný klast bazaltu.

Fig. 3: Striated basalt clast. uvedené horniny vystupují na povrch nebo jsou skryty pod kvarterními sedimenty (Sawicki 1995).

Klasty nordické provenience tvoří ponejvíce červené granitoidy a porfyry, doprovázené pískovci, pelosideritovými a Fe-konkrecemi a pazourky. Polské horniny představují sudetský porfyr a silicity. Původ bazaltů je podle dosavadních názorů převážně místní, ale mohl by být i nordický (viz diskuzi v práci Gáby - Peka 1999), proto je bazalt v tab. 1 vyčleněn samostatně.

Křemen je představován jak samostatnými klasty, tak klasty se zachovanými zbytky dalších minerálů nebo i horniny, jichž byl křemen původně součástí (načervenalé živce, slídy, granát, zbytky kvarcitů). Většina křemenných klastů bude provenienčně souviset s rychlebskými metamorfity.

Balvany vykazují toto složení: nordika $\sim 43 \%$, bazalt $\sim 30 \%$, gieraltowská rula $\sim 15 \%$, křemen $\sim 3 \%$, kvarcit $\sim 1,5 \%$, šedý biotitický granitoid $\sim 1,5 \%$, amfibolit $\sim 1,5 \%$, neurčitelné horniny $\sim 5 \%$. Metamorfity pocházejí z hlavního hřebene Rychlebských hor nebo z přilehlého Polska, šedý biotitický granitoid $\mathrm{z}$ variských masivů v okolním krystaliniku. Nordické balvany tvoří hlavně granitoidy a mnohem vzácněji porfyry. Zajímavostí je nezvykle vysoký podíl bornholmských deformovaných granitů ( 11\% balvanů), protože tato hornina jinak není v asociaci nordik na Jesenicku hojná (Gába - Pek 1999). Nordickou provenienci by tak mohlo mít podstatně více bazaltů než se dosud předpokládalo, protože bazaltové výchozy leží i na švédském poloostrově Skåne nedaleko Bornhomu (Hesemann 1975). Zhruba 8 \% balvanů nese na povrchu exarační rýhy. Zjištěny byly jen na měkkém zvětralém povrchu bazaltových balvanů (i menších klastů, viz obr. 3) a na nordických horninách, jejichž pevný povrch je někdy i vyhlazený ledovcovou abrazí (obr. 4).

\section{Interpretace a diskuze Vznik a určení sedimentů}

Balvanitý horizont na bázi nejspodnějšího diamiktonu vznikl při posouvání největších klastů po miocenním podloží v bazální zóně ledovce. Balvany se třely o částečně plastické a hutné písky, případně se do nich zarývaly, až se jejich pohyb zastavil. Přes zafixované balvany byly

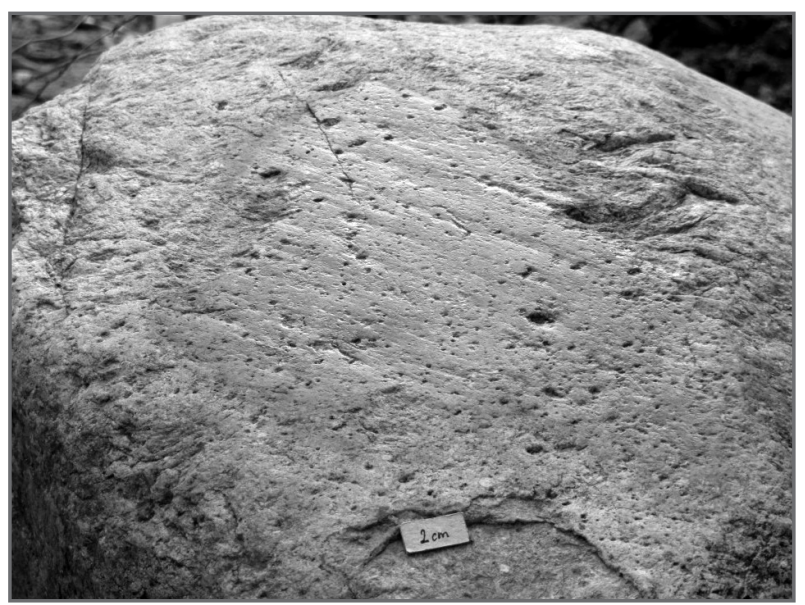

Obr. 4: Rýhovaný ledovcový ohlaz na povrchu nordického balvanu.

Fig. 4: Striated and polished surface of a Nordic boulder. 
posouvány další klasty, které povrch některých balvanů i svůj vlastní abradovaly za vzniku hladkých ploch a rýhovaly. Zablokování velkých klastů do měkkého podloží ledovce a jejich následná abraze a exarace jsou typickými znaky lodgement tillů (Evans et al. 2006). Tuto interpertaci podporuje i stavba akumulace Jk1b, v níž jsou na sebe akretovány různé dílčí facie. Vzhledem $\mathrm{k}$ hrubozrnnosti diamiktonů zde nejsou vyvinuty pro lodgement tilly typické hladké střižné plochy. Vyvlékání nezpevněných podložních hornin do diamiktonů a smíchání ledovcem transportovaného detritu s útržky podložního materiálu jsou zase projevy ledovcové deformace podloží (Eyles Boyce 1998) a znaky glacitektonitů (Benn - Evans 1996, Evans et al. 2006). Klasifikace a terminologie tillů vzniklých ukládáním materiálu $\mathrm{z}$ ledovcové báze na straně jedné a tillů vzniklých deformací podloží na straně druhé je problematická, protože tyto procesy se uplatňovaly při vzniku obou typů sedimentů, které pak mají podobné znaky (Ruszczyńska-Szenajch 2001). Glacitektonity a deformační tilly se ovšem vyznačují pozvolným přechodem od nepostiženého podloží, které je směrem nahoru stále intenzivněji deformované až nakonec přechází do homogenních diamiktonů (Evans et al. 2006). V př́padě Písečníku jsou od sebe miocenní písky a nejspodnější diamiktony ostře odděleny erozním povrchem a jsou zřetelně litologicky odlišné. Glacitektonické deformační jevy jsou malého měřítka a sporadické. $Z$ tohoto důvodu a na základě výše uvedených znaků lze nejspodnější diamikton označit jako lodgement till.

Nadložní sedimenty (Jk2) se od lodgement tillu odlišují jen absencí velkých klastů a prrítomností šikmého zvrstvení. Jedná se o výplň mělké subglaciální deprese v lodgement tillu, ve které docházelo zpočátku ke gravitační až fluviální resedimentaci materiálu tohoto tillu. Intenzita fluviální aktivity narůstala postupně s vyplňováním deprese, protože v nejvyšší části se již jedná o zřetelně šikmo zvrstvené glacifluviální písky (Jk2b). Deprese v tillech vyplněné glacifluviálními faciemi se v subglaciálním prostř̌edí běžně vyskytují (Eyles et al. 1983). V tomto př́ípadě byl průběh subglaciálního toku nejspíš predisponován depresním reliéfem lodgement tillu, který zase kopíroval výmolovou bázi v miocenním podloží.

Svrchní část vrstevního sledu (Jk3-Jk5) představují supraglaciální facie, které se vyvíjely při povrchovém odtávání stagnujícího ledovce. Supraglaciální prostředí se vyznačuje značnou variabilitou morfologie terénu i facií (Brodzikowski - Van Loon 1991). Ledovec neodtává od povrchu rovnoměrně, ale $\mathrm{v}$ závislosti na průběhu puklin v ledu a na rozložení detritu v ledovcovém tělese získává povrch degradujícího ledovce podobu elevací a depresí. Každá elevace je tvořena ledovým jádrem, pokrytým původně supraglaciálním a englaciálním detritem, jenž se uvolňuje z roztávajícího ledu. $V$ depresích se hromadí sedimenty úlomkotoků, transportovaných z elevací. Štěrkový horizont (Jk3) může být výsledkem sesunutí a souběžného gravitačního vytř́iění hrubého materiálu po svahu zbývajícího ledového jádra (Kjær - Krüger 2001). Písčitý člen Jk4 je sedimentem malého toku nebo supraglaciálního jezírka. Drobné říčky a různě velké jezerní nádrže jsou charakteri- stickou složkou supraglaciálního prostředí (Brodzikowski - Van Loon 1991, Kjær - Krüger 2001). Písčitý štěrk (Jk5) i stejný sediment ve východní stěně (obr. 2e) představují supraglaciální melt-out till, eventuálně jeho materiál krátce resedimentovaný supraglaciálními toky nebo gravitačními proudy (skluzy z ledových elevací). Orientovanému transportu, předcházejícímu samotnou depozici, napovídá shodné uklonění plochých klastů (Brodzikowski - Van Loon 1991) a na vliv tavné vody ukazuje určité vytřídění projevující se úbytkem jemných frakcí. Interpretaci členu Jk4 jako sedimentů drobné říčky nebo nádrže, stejně jako interpretaci členu Jk2 jako výplně omezené subglaciální dutiny podporuje i omezený plošný rozsah těchto členů, protože v pravé části západní stěny a ve východní stěně nejsou vyvinuty a na lodgement till přímo nasedají hrubozrnné supraglaciální facie (obr. 2a, e).

Masivní hrubé štěrky až diamiktony s podpůrnou strukturou základní hmoty vznikají i v terminoglaciálním prostředí koncových morén, ovšem tam dosahují mnohem větších mocností několika m i prvních desítek $\mathrm{m}$ a laterálního rozsahu $\mathrm{v}$ desítkách až stovkách $\mathrm{m}$ (např̀ Kozarski 1995, Pisarska-Jamroży 2006). Takto rozsáhlé depoziční prostředí nelze na Písečníku vzhledem $\mathrm{k}$ jeho jasnému omezení předpokládat. Zde se jednalo o nevelké pole morén s ledovým jádrem (ice-cored moraine), které postupně přešlo do pole s akumulacemi supraglaciálního materiálu zbylého po roztátém ledu (dead-ice moraine), viz Kjær - Krüger (2001). Tyto facie dosahují mocnosti max. několika m (Brodzikowski - Van Loon 1991). Depoziční prostředí se tedy podobalo svým recentním analogiím na polytermálních ledovcích (obr. 5, 6), dalšími procesy však byla původní kopečková morfologie na Písečníku destruována.

Petrografické složení potvrzuje faciální genetickou interpretaci. Lodgement till obsahuje převážně gierałtowskou rulu, jelikož se uložil pouze $z$ detritu transportovaného na bázi ledovce, který vznikal hlavně erozí bezprostředního podloží ledovce. V těsném předpolí Rychlebských hor erodoval ledovec nejpravděpodobněji aluviální až fluviální sedimenty, v nichž musela gierałtowská rula dominovat, vzhledem $\mathrm{k}$ jejímu rozhodující-

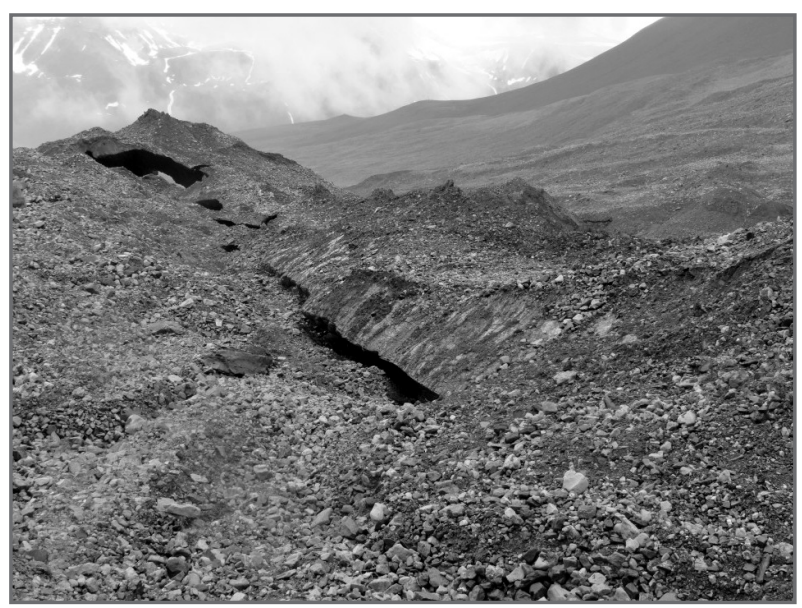

Obr. 5: Moréna s ledovým jádrem. Ledovec Bertil, centrální Svalbard.

Fig. 5: Ice-cored moraine, Bertilbreen, Central Svalbard. 


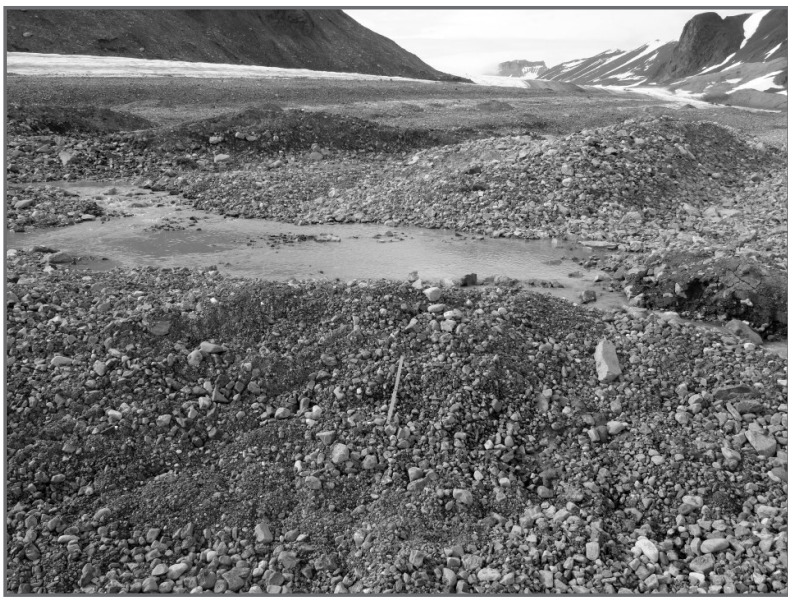

Obr. 6: Materiál uvolněný povrchovým táním ledovce a resedimentovaný supraglaciálními toky. Ledovec Hørbye, centrální Svalbard.

Fig. 6: Material released by superficial glacier thawing and reworked by supraglacial streams, Hørbyebreen, Central Svalbard.

mu podílu na petrografické stavbě přilehlého horského hřebene. Sedimenty bezprostředně nad lodgement tillem (Jk2) vznikly resedimentací materiálu tohoto tillu, jelikož se s ním petrograficky shodují. Šikmé zvrstvení dokládá vliv proudící vody, takže se jednalo o subglaciální depresi, které se vytvářejí mj. v rané fázi vývoje morén s ledovým jádrem (Kjær - Krüger 2001). Členy Jk1 a Jk2 tedy představují subglaciální sekvenci vrstevního sledu. Nadložní členy Jk3-Jk5 potom reprezentují supraglaciální sekvenci. Je pro ně typická polymiktnost $s$ vyššími podíly materiálu vzdálené provenience (viz také Sikorová et al. 2006). Zároveň se vyznačují větší variabilitou zaoblení klastů, projevující se mírným nárůstem podílů angulárních a oválných tvarů. Petrografická i tvarová pestrost materiálu byla podmíněna jeho prŕnosem ze supraglaciálního i englaciálního prostředí, jak byly klasty postupně uvolňovány při povrchovém odtávání. Výskyt rychlebských metamorfitů z původního podloží ledovce lze vysvětlit jejich vynášením podél násunových ploch $\mathrm{v}$ ledovci, což je běžný mechanizmus transportu subglaciálního materiálu na povrch ledovců v jejich čelní ćásti (Bennett et al. 1997, Benn - Evans 2010). Narůst podílu oválných a dokonale oválných klastů odráží př́nos englaciálního materiálu, pro nějž je vysoký stupeň zaoblení charakteristický („egg gravels“, Bennett et al. 1997). V supraglaciálních členech také nápadně přibývá klastů křemene bez zbytků okolní horniny, které jsou podstatně lépe zaoblené než klasty křemene s pozůstatky okolní horniny. Větší variabilita zaoblení supraglaciálního materiálu oproti subglaciálnímu je doložena ze současných ledovců (napr. Bennett et al. 1997, Hambrey - Ehrmann 2004). V členech Jk3-Jk5 se také oproti členům Jk1-Jk2 hojněji projevuje eolizace, což lze vysvětlit mnohem dlouhodobější expozicí supraglaciálního materiálu.

Supraglaciální sedimenty mají nízký potenciál zachování, jelikož jsou ve velké míre destruovány následnými glacifluviálními procesy a proto jsou i na našem území vzácné (Růžičková et al. 2003). Sukcese subglaciálních (hlavně lodgement) tillů a supraglaciálního detritu v prímé superpozici jsou typické pro polytermální ledovce (Ham-

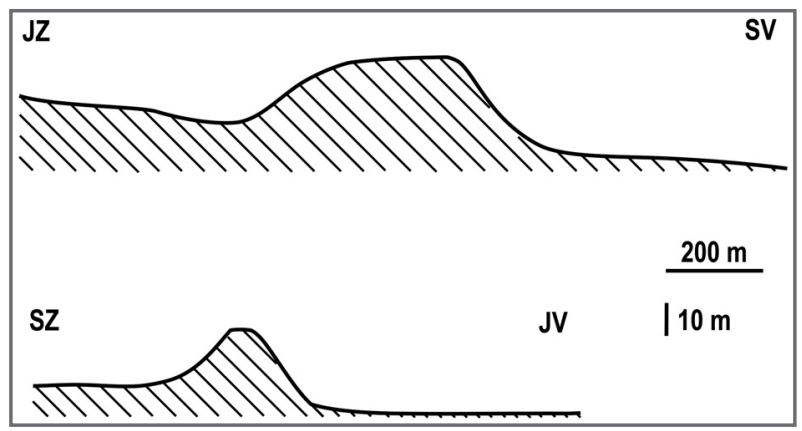

Obr. 7: Schematický řez Písečníkem ve směru JZ-SV (nahoře) a SZ-JV (dole). 10× převýšeno.

Fig. 7: Sketch sections through the Písečník Hill in the SW-NE direction above and NW-SE direction below. 10 times exaggerated.

brey - Glasser 2012) a byly popsány z mnoha fosilních př́kladů (např. Johansson 1983, Lindner 1995, Raukas 1995, Růžičková et al. 2003). Lodgement tilly jsou většinou zřetelně jemnozrnnější a supraglaciální tilly naopak štěrkovitější v důsledku odnosu jemné frakce tavnou vodou povrchově odtávajícího ledovce. Hrubozrnnost lodgement tillů na Písečníku je odvozena od zdrojového materiálu na bázi ledovce, kterým byly nejpravděpodobněji aluviální až fluviální uloženiny. Tyto musely být bohaté na detrit, uvolněný ze skalního podloží budujícího svahy Rychlebských hor.

\section{Písečník jako tvar reliéfu zaledněného území}

Písečník je izolovaný hřbet protažený ve směru SV$\mathrm{JZ} s$ prríkrou stranou obrácenou $\mathrm{k} S \mathrm{~S}$ a pozvolnou stranou orientovanou k JZ (obr. 1, 7). Jádro elevace je tvořeno relativně kompaktním, i když nelitifikovaným předkvartérním podložím, na němž spočívají subglaciální lodgement tilly. Podle těchto znaků lze Písečník interpretovat jako drumlin tvořený podložními horninami a na nich ležícími tilly (part bedrock/part till drumlin, Stokes et al. 2011). Pro tyto drumliny jsou typické i glacitektonické jevy (Meehan et al. 1997), které byly na Písečníku v omezené míře zjištěny. Orientace drumlinu naznačuje postup ledovce od SV. Pevninský ledovec se v předpolí sudetského okrajového zlomu šíril různými směry, včetně směru SV-JZ (Badura et al. 1998). Orientace drumlinu tudíž není v rozporu s paleogeografickými rekonstrukcemi v dané oblasti, jelikož postup od SV je jedním z předpokládaných směrů šíření kontinentálního ledovce. Podobným směrem (VSV-ZJZ) je orientována i méně výrazná elevace s osadou Kohout (266 m n. m.), ležící 500 m ssv. od Písečníku, která by tak mohla př̀edstavovat další drumlin, viz obr. 1.

Ledovcové sedimenty tvořící drumliny většinou náleží subglaciálním faciím (Stokes et al. 2011). Při pohybu přes elevace však v ledovcích vznikaly příčné trhliny, které pak během následného povrchového odtávání urychlily rozpad ledovců na jednotlivé kry a tvorbu morén s ledovým jádrem. Takto narušené, na elevacích stagnující ledovce nakonec zcela roztály za vzniku supraglaciálních facií, které se uložily na subglaciální sedimenty (Eyles et al. 1999, Kjær - Krüger 2001). 


\section{Závěr}

Vývoj Písečníku během zalednění lze rekapitulovat následovně. Kontinentální ledovec se do studované oblasti rozšiŕil od SV a pokryl celou elevaci, která existovala již před zaledněním. Přitom deformoval minimálně připovrchovou zónu podloží. Plastické miocenní písky zablokovaly velké klasty na bázi ledovce, čímž vznikla balvanitá poloha jako bazální zóna lodgement tillu. Při pohybu přes elevaci ledovec rozpukal př́čnými trhlinami. Na počátku deglaciace docházelo $\mathrm{v}$ dutinách na bázi ledovce $\mathrm{k}$ resedimentaci materiálu lodgement tillu. Následovalo pozvolné povrchové odtávání ledovce, při němž vznikaly morény s ledovým jádrem. Po úplném roztátí ledovce zůstaly na povrchu faciálně pestré supraglaciální sedimenty, nasedající na lodgement till a výplně subglaciálních dutin. Písečník lze podle geologické stavby a povrchové morfologie interpretovat jako drumlin tvořený podložními horninami a na nich ležícími tilly (part bedrock/part till drumlin, Stokes et al. 2011). Orientace drumlinu naznačuje směr postupu ledovce od SV, což koresponduje s dosavadními paleogeografickými rekonstrukcemi.

\section{Poděkování}

Výzkum byl podpořen projektem „Vytvoření pracovního týmu a pedagogických podmínek pro výuku a vzdělávání $v$ oblasti polárni ekologie a života v extrémním prostředi", reg. č. CZ.1.07/2.2.00/28.0190., v jehož rámci bylo možné studovat supraglaciální sedimentaci na současných polytermálních ledovcích na Svalbardu a tím použit recentní př́klady pro interpretaci fosilnich ledovcových sedimentů. 
Literatura

Badura, J. - Krzyszkowski, D. - Przybylski, B. (1998): Stratygrafia glin lodowcowych, liczba zlodowaceń i kierunki transportu lodowcowego w południowej części przedgórza sudeckiego (okolice Ząbkowic), Polska południowo-zachodnia. - Biuletyn Państwowego instytutu geologicznego, 385, 29-48.

Benn, D. I. - Evans, D. J. A. (1996): The interpretation and classification of subglacially-deformed materials. - Quaternary Science Reviews, 15, 23-52.

Benn, D. I. - Evans, D. J. A. (2010): Glaciers and Glaciatons - Hodder Education, 802 pp.

Bennett, M. R. - Hambrey, M. J. - Huddart, D. (1997): Modification of clast shape in high-arctic glacial environment. - Journal of Sedimentary Research, 67, 3, 550-559.

Brodzikowski, K. - Van Loon, A. J. (1991): Glacigenic Sediments - Elsevier, 674 s.

Evans, D. J. A. - Phillips, E. R. - Hiemstra, J. F. - Auton, C. A. (2006): Subglacial till: Formation, sedimentary characteristics and classification. - Earth-Science Reviews, 78, 115-176.

Eyles, N. - Boyce, J. I. (1998): Kinematic indicators in fault gouge: tectonic analog for soft-bedded ice sheets. - Sedimentary Geology, 116, 1-12.

Eyles, N. - Boyce, J. I. - Barendregt, R. W. (1999): Hummocky moraine: sedimentary record of stagnant Laurentide Ice Sheet lobes resting on soft beds. - Sedimentary Geology, 123, 163-174.

Eyles, N. - Eyles, C. H. - Miall, A. D. (1983): Lithofacies types and vertical profile models; an alternative approach to the description and environmental interpretation of glacial diamict and diamictite sequences. - Sedimentology, 30, 393-410.

Gába, Z. - Pek, I. (1999): Ledovcové souvky moravskoslezské oblasti. - Okresní vlastivědné muzeum v Šumperku, 111 s.

Hambrey, M. J. - Ehrmann, W. (2004): Modification of sediment characteristics during glacial transport in high-alpine catchments: Mount Cook area, New Zealand. - Boreas, 33, 300-318.

Hambrey, M. J. - Glasser, N. F. (2012): Discriminating glacier thermal and dynamic regimes in the sedimentary record. - Sedimentary Geology, 251-252, 1-33.

Hesemann, J. (1975): Kristalline Geschiebe der nordischen Vereisungen. - Geologisches Landesamt Nordrhein-Westfalen, 267 s.

Johansson, H. G. (1983): Tills and moraines in northern Sweden. - In: Ehlers, J. (ed.): Glacial deposits in North-West Europe, 123-130, A. A. Balkema.

Kjær, K. H. - Krüger, J. (2001): The final phase of dead-ice moraine development: processes and sediment architecture, Kötlujökull, Iceland. - Sedimentology, 48, 935-952.

Kozarski, S. (1995): Large-clast flow tills in end moraines of southwestern Pomerania, NW Poland. - In: Ehlers, J. - Kozarski, S. - Gibbard, P. (eds): Glacial deposits in North-East Europe, 301-307, A. A. Balkema.

Lindner, L. (1995): Till sequences and local moraines in the Holy Cross Mountains area in central Poland. - In: Ehlers, J. - Kozarski, S. - Gibbard, P. (eds.): Glacial deposits in North-East Europe, 329-337, A. A. Balkema.

Meehan, R. T. - Warren, W. P. - Gallagher, C. J. D. (1997): The sedimentology of a Late Pleistocene drumlin near Kingscourt, Ireland. - Sedimentary Geology, 111, 91-105.

Pecina, V. - Čurda, J. - Hanáček, M. - Kočandrle, J. - Nývlt, D. - Opletal, M. - Skácelová, D. - Skácelová, Z. - Večeřa, J. - Žáček, V. (2005): Základní geologická mapa České republiky 1: 25000 list 14-221 Žulová s Vysvětlivkami. - MS, Česká geologická služba.

Pisarska-Jamroży, M. (2006): Transitional deposits between the end moraine and outwash plain in the Pomeranian glaciomarginal zone of NW Poland: a missing component of ice-contact sedimentary models. - Boreas, 35, 126-141.

Pouba, Z. (1996): Geologická mapa ČR. Mapa předčtvrtohorních útvarů $1: 200$ 000. List Jeseník. - Český geologický ústav.

Pouba, Z. - Dvořák, J. - Kužvart, M. - Mísař, Z. - Musilová, L. - Prosová, M. - Röhich, P. - Skácel, J. - Unzeitig, M. (1962): Vysvětlivky k přehledné geologické mapě ČSSR 1:200 000, list M-33-XVIII Jeseník. - Ústřední ústav geologický.

Powers, M. C. (1953): A new roundness scale for sedimentary particles. - Journal of Sedimentary Petrology, 23, 117-119.

Raukas, A. (1995): Properties, origin and stratigraphy of Estonian tills. - In: Ehlers, J. - Kozarski, S. - Gibbard, P. (eds.): Glacial deposits in North-East Europe, 93-101, A. A. Balkema.

Ruszczyńska-Szenajch, H. (2001): “Lodgement till” and “deformation till”. - Quaternary Science Reviews, 20, 579-581.

Růžičková, E. - Růžička, M. - Zeman, A. - Kadlec, J. (2003): Kvartérní klastické sedimenty České republiky. Struktury a textury hlavních genetických typů. - Česká geologická služba, $68 \mathrm{~s}$.

Sawicki, L. (1995): Mapa geologiczna regionu Dolnośląskiego z przyległymi obszarami Czech i Niemiec (bez utworów czwartorzędowych) $1: 100$ 000. - Państwowy instytut geologiczny.

Sikorová, J. - Víšek, J. - Nývlt, D. (2006): Texture and petrography of glacial deposits in the northern foothill of the Hrubý Jeseník and Rychlebské Mts., Czechia. - Geological Quarterly, 50, 3, 345-352.

Stokes, Ch. R. - Spagnolo, M. - Clark, Ch. D. (2011): The composition and internal structure of drumlins: Complexity, commonality, and implications for a unifying theory of their formation. - Earth-Science Reviews, 107, 398-422.

Svoboda, J. - Chaloupský, J. - Bernard, J. - Dornič, J. - Kalášek, J. - Klein, V. - Malkovský, M. - Mísař, Z. - Pacovská, E. - Pauk, F. - Řezáč, B. - Skácel, J. - Soukup, J. - Tásler, R. - Vodička, J. - Zrůstek, V. (1961): Vysvětlivky k přehledné geologické mapě ČSSR $1: 200$ 000, M - 33 - XVII Náchod. - Ústřední ústav geologický.

Žáček, V. (1995): Geologická mapa ČR 1 : 50 000. List 14-22 Jeseník. - Český geologický ústav. 